\title{
KEMAMPUAN BERPIKIR MATEMATIS DALAM KONTEKS PEMBELAJARAN ABAD 21 DI SEKOLAH DASAR
}

\author{
Muhammad Fajri, S.Pd \\ SDN Pondok Petir 01, Bojongsari, Kota Depok \\ Jl. Reni Jaya Selatan, Pondok Petir, Bojongsari, Kota Depok \\ fkm.jrie27@gmail.com \\ Submitted: 10-05-2017, Reviewed: 03-06-2017, Accepted: 28-08-2017
}

\begin{abstract}
Developing the mathematical thinking be authorized in the context of the current of meaningfull learning. Learning for $21^{\text {st }}$ century paradigm replace that generally provide a broad space on the developmental aspects and student learning tasks as learning subject. The context appears as the implications of the development of high order thinking skills that need to be optimized in the learning process as learning principles in the curriculum of 2013. The purpose of this paper to explain the concepts and principles that can be developed related to the mathematical thinking in the context of 21 st century learning. The principles of 21 st century learning also become the foundation as one of the basic considerations in the process of benchmarking and the development of curriculum changes that will be applied. The mathematical thinking identified in 5 components, among others: (1) understanding of mathematics; (2) solving mathematical problems; (3) mathematical reasoning; (4) The mathematical connection; (5) mathematical communication. Affiliated to the five components that are interconnected is, the learning process that leads to the 21 century learning can go hand in hand in making them. Development of materials and processes which are affiliated with aspects of learning and development of students form the basis for determining the direction and purpose of education that lead to the learning process in the classroom. The results of the analysis of the content is based on theoretical studies indicate alignment between the development of the mathematical thinking the learning context of the 21st century requires the development of high-level thinking skills for students, especially in elementary school.
\end{abstract}

Key words: Mathematical Thinking, Learning for $21^{\text {st }}$ century

\begin{abstract}
Abstrak. Pengembangan kemampuan berpikir matematis menjadi modal dasar dalam konteks pembelajaran yang bermaknasaat ini. Pembelajaran abad 21 menggeser paradigma yang secara umum memberikan ruang gerak lebih luas pada aspek perkembangan dan tugas belajar siswa sebagai subjek pembelajaran. Konteks tersebut muncul sebagai implikasi dari pengembangan high order thinking skill yang perlu dioptimalkan dalam proses pembelajaran sebagaimana prinsip-prinsip pembelajaran pada kurikulum 2013. Tujuan penulisan ini untuk memaparkan konsep dan prinsip yang dapat dikembangkan terkait kemampuan berpikir matematis. Prinsipprinsip pembelajaran abad 21 juga menjadi dasar pijakan sebagai salah satu dasar pertimbangan dalam proses benchmarking perubahan dan pengembangan kurikulum yang akan diterapkan. Kemampuan berpikir matematis diidentifikasi dalam 5 komponen, antara lain: (1) pemahaman matematika; (2) pemecahan masalah matematik; (3) penalaran matematik; (4) koneksi matematik; (5) komunikasi matematik. Berafiliasi pada kelima komponen yang saling berhubungan tersebut, proses pembelajaran yang bermuara pada pembelajaran abad 21 dapat seiring sejalan dalam mewujudkannya. Pengembangan materi dan proses pembelajaran yang berafiliasi pada aspek dan perkembangan siswa menjadi landasan dalam menentukan arah dan tujuan pendidikan yang bermuara pada proses pembelajaran di kelas. Hasil analisis konten berdasarkan kajian teoretik menunjukkan adanya keselarasan antara pengembangan kemampuan berpikir matematis dengan konteks pembelajaran abad 21 yang menuntut adanya pengembangan kemampuan berpikir tingkat tinggi bagi siswa khususnya di SD.
\end{abstract}

Kata kunci: Berpikir Matematis, Pembelajaran Abad 21 


\section{PENDAHULUAN}

Pembelajaran abad 21 memberikan gambaran nyata tentang bagaimana sebuah situasi yang dikondisikan sebagai bentuk proses pembelajaran yang ideal. Ideal di sini memberikan makna bahwa proses pembelajaran yang dilaksanakan saat ini merupakan representasi dari pengalaman berharga dari siswa ketika dirinya akan menghadapi kenyataan pada masa yang akan datang. Deangan asumsi tersebut, konsekuensi pembelajaran yang harus dijalankan harus benar-benar mencerminkan kondisi dan situasi pada masa yang akan datang (futuristik) sehingga konteks yang dipelajari siswa nantinya adalah apa yang akan mereka alami dalam proses kehidupannya di masa yang akan datang. Paradigma pembelajaran yang berkembang saat ini menunjukkan adanya pergeseran dalam hal proses pembelajaran yang dilaksanakan. Hal tersebut juga berimplikasi secara langsung terhadap konteks pembelajaran yang dilaksanakan di kelas sebagaimana seharusnya. Hal tersebut sebagaimana prinsip-prinsip pengembangan kurikulum 2013 yang memberikan ruang gerak lebih luas dan perhatian lebih kepada siswa sebagai peserta belajar dalam konteks subjek sekaligus objek pembelajaran yang dilaksanakan.

Ranah pembelajaran yang dijalankan saat ini, sebagaimana tuntutan kurikulum yang dikembangkan lebih mengedepankan aspek kebutuhan siswa baik dilihat dari segi psikologis, tugas belajar, maupun fisik dan kognitifnya. Dalam proses pembelajaran yang dilaksanakan, paradigma kontrukstivistik lebih kental dibandingkan prinsip tabula rasa dari segi siswa itu sendiri. Model pengembangan pembelajaran yang lebih mengedepankan aspek dan perkembangan siswa sebagai peserta didik menjadi satu dasar yang harus diprioritaskan terkait konsep pembelajaran yang dijalankan. Pengembangan keterampilan berpikir tingkat tinggi (high order thinking skill) telah tertuang dalam konteks kurikulum 2013 yang telah mengalami revisi terakhir pada 2016 lalu. Konteks tersebut dapat dilihat pada kompetensi-kompetensi pembelajaran yang pada umumnya mengindikasikan pengembangan keterampilan berpikir tingkat tinggi. Kerangka konseptual pengembangan keterampilan berpikir tingkat tinggi secara jelas tersurat dalam kompetensi yang dikembangkan sesuai Permendikbud RI.

Secara konseptual, ranah pengembangan kemampuan berpikir matematis telah tersurat dalam rangkaian kompetensi pembelajaran yang dituangkan dalam Permendikbud RI Nomor 24 Tahun 2016 tentang Kompetensi Inti dan Kompetensi 
Dasar Satuan Pendidikan Dasar dan Menengah. Pada pembelajaran matematika khususnya, dimensi berpikir matematis tertuang dalam rangkaian kompetensi pembelajaran yang secara hierarkis menjadi satu kecakapan khusus yang harus dikuasai seorang siswa dalam satuan pendidikan dasar khususnya. Dalam proses pembelajaran yang dilaksanakan, kemampuan berpikir matematis sebagai satu konsep mendasar bagi siswa di Sekolah Dasar (SD) untuk dapat mengembangkan kemampuan berpikirnya harus senantiasa diberikan treathment dalam rangka peningkatan dan pengembangan kemampuan berpikir matematisnya. Selain itu, yang perlu dicermati lainnya bahwa dalam proses pembelajaran matematika, siswa dilatih cara berpikir dan bernalar dalam menarik suatu kesimpulan melalui kegiatan penyelidikan, eksplorasi, eksperimen, menunjukkan kesamaan dan perbedaan, konsisten dan inkonsistensi (Kusumaningrum dan Saefudin, 2012: 572). Dalam beberapa kompetensi tersebut, hampir pada umumnya kompetensi yang dikembangkan bersifat keterampilan berpikir tingkat tinggi (high order thinking skill). Oleh karenanya, melalui proses pembelajaran matematika dapat dikembangkan konteks berpikir tingkat tinggi sebagai satu diantaranya hal lainnya yang merupakan kompetensi yang perlu dikuasai siswa dalam proses pembelajaran abad 21 ini.

\section{METODE PENELITIAN}

Nichols (dalam http://www.teachthought.com/learning/4-essential-rules-of-21stcentury-learning/) mendeskripsikan 4 konsep pembelajaran abad 21, antara lain: (1)instruction should be student centered; (2)education should be collaborative; (3)learning should have context; (4)schools should be integrated with society. Dari keempat konsep tersebut, merupakan satu dasar kesatuan yang memberikan implikasi terhadap proses pembelajaran yang harus dilaksanakan. Pentingnya proses pembelajaran yang memberikan ruang gerak lebih leluasa kepada siswa untuk mengekspresikan dirinya dalam suasana lingkungan belajar yang menantang perlu dipikirkan. Proses tersebut memberikan perhatian yang lebih kepada siswa sebagai subjek sekaligus objek pembelajaran yang perlu diidentifikasikan kebutuhan baik secara fisik, psikologis, maupun kognitifnya. Dari segi tugas belajarnya, siswa tentu memiliki dasar asumsi yang perlu dicermati seiring sejalan dengan pembelajaran yang harus dilakukan. Dengan demikian, keempat konsep pembelajaran abad 21 ini dapat diimplementasikan dalam 
suasana belajar yang sesungguhnya untuk ketercapaian proses pembelajaran yang bersifat meaningfull learning.

Dalam pengembangannya, konsep pembelajaran abad 21 yang memberikan tantangan global terhadap generasi yang saat ini sedang berkembang tentu perlu diperhatikan kebutuhan belajar seperti apa yang nantinya mereka perlukan dalam proses kehidupannya yang akan datang. Karena, pada dasarnya siswa belajar saat ini untuk bekal dalam kehidupannya pada masa yang akan datang. Jika demikian, maka pendidikan yang futuristik harus dicermati secara komprehensif. Hal tersebut tidak lain adalah demi tercukupinya kebutuhan material konseptual dari konsep materi pembelajaran yang diperlukan sesuai konteks perkembangan kehidupan siswa pada masa yang akan datang. Dalam konteks pembelajaran yang dikembangkan saat ini, sebagaimana konsep pembelajaran abad 21 ini, pengembangan keterampilan berpikir tingkat tinggi (high order thinking skill) menjadi satu acuan dalam hal pengembangan proses pembelajaran yang optimal. Pengembangan keterampilan berpikir tingkat tinggi ini menjadi satu konsep baru dalam ranah pengembangan kognitif siswa yang tertuang dalam kurikulum 2013 (sebagaimana revisi 2016). Hal lain berimplikasi pada paradigma pembelajaran yang harus dilaksanakan. berikut dapat dicermati hal-hal yang terkait dengan pembelajaran abad 21 sebagaimana dikembangkan oleh Partnership for $21^{\text {st }}$ Century Learning.

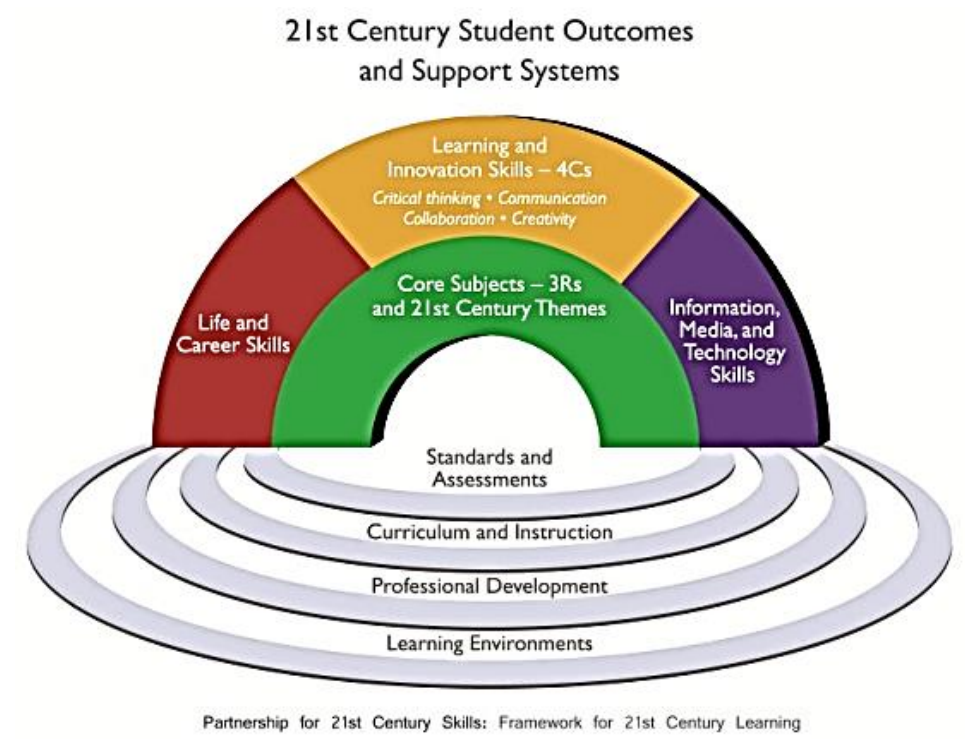

Gambar 1. Framework Partnership for $21^{\text {st }}$ Century Skills. (Alismail dan McGuire, 2015) 
Pada proses pembelajaran matematika, pengembangan kompetensi siswa dalam hal berpikir untuk menyelesaikan suatu persoalan menjadi dasar pengembangan pembelajaran yang dilaksanakan. Proses berpikir matematis dilaksanakan dengan memberikan berbagai permasalahan kontekstual yang familiar dengan kehidupan siswa untuk diselesaikan secara optimal oleh siswa dalam konteks pembelajaran matematika yang menarik bagi siswa. Ibrahim dan Nur (dalam Darminto, 2008) berasumsi bahwa berpikir merupakan kemampuan untuk menganalisis, mengkritik, dan mencapai kesimpulan berdasarkan inferensi atau pertimbangan yang seksama. Di samping itu, Marpaung (dalam Darminto, 2008) memberikan batasan terhadap konsep berpikir sebagai suatu aktifitas yang dimulai dari usaha untuk menemukan informasi (dari luar atau diri siswa), mengolah, menyimpan, dan memanggil kembali informasi dari ingatan siswa. Lebih lanjut, Muijs dan Reynolds (2008) menyatakan bahwa penyebab keterampilan berpikir perlu dipelajari siswa adalah adanya berbagai penelitian yang menunjukkan adanya korelasi antara berpikir siswa dan prestasinya di berbagai mata pelajaran di sekolah. Selain itu, disebabkan juga oleh adanya perubahan di lingkungan sosial siswa yaitu perubahan terhadap pengetahuan informasi yang menjadi semakin kompleks dan berkembang dengan cepat. Dengan asumsi tersebut, maka pengembangan proses berpikir siswa perlu dikembangkan secara efektif dan optimal sebagai satu bentuk kompetensi pembelajaran terhadap bekal dan kecakapan siswa dalam menghadapi kenyataan dan tantangan kehidupan pada masanya yang akan datang.

Schoenfeld (1992) menyatakan bahwa berpikir matematis merupakan proses mengembangkan sudut pandang matematis-menghargai proses matematisasi serta memiliki keinginan kuat untuk menerapkannya, dan mengembangkan kompetensi dan melengkapi diri dengan segenap perangkap, lalu pada saat yang sama menggunakan perangkat tersebut untuk memahami struktur pemahaman matematika. Berdasarkan asumsi tersebut, konsep matematis menjadi suatu hal yang bersifat praktis dalam proses pembelajarannya melalui keinginan untuk menerapkannya. Konsep-konsep matematis yang dipelajari divisualisasikan secara kontekstual untuk dapat menjembatani pengetahuan siswa dalam memahami hal-hal abstrak secara konkrit dalam pembelajarannya. Dengan demikian kompetensi matematis yang diharapkan untuk dapat dikuasai siswa dalam dipelajari dengan mudah dan dengan cara yang familiar dengan kehidupan siswa sehari-hari. 
Dalam hal proses berpikir matematis ini, Sumarno (2006) memiliki 4 konsep yang berkaitan dengan berpikir matematis (mathematical thinking), yaitu: (1) kemampuan matematik (mathematical abilities); (2) keterampilan matematik (mathematical skill); (3) melaksanakan proses matematik (doings mathematics); (4) tugas matematika (mathematical task). Dari keempatnya, dapat diidentifikasi masingmasing bahwa berpikir matematika dapat diasumsikan sebagai implementasi dalam melaksanakan kegiatan atau proses matematika (doing math) atau tugas matematik (mathematical task). Dalam proses pembelajaran matematika di SD khususnya, keempat konsep yang dikembangkan tersebut merupakan satu kesatuan utuh yang harus dikuasai siswa sebagai bentuk kompetensi matematis yang dikorelasikan dengan materi pembelajaran matematika pada masing-masing level kelasnya. Dengan demikian, konsep matematis secara teoretis perlu dipelajari juga oleh siswa sebagai kecakapan matematis yang dipelajari dalam konteks pembelajaran praksis di kelas.

\section{Dimensi Berpikir Matematis}

Kemampuan berpikir matematis merupakan bentuk akumulasi dari konsep berpikir secara matematis yang mengindikasikan adanya pengembangan kemampuan: (1) pemahaman matematika; (2) pemecahan masalah matematik; (3) penalaran matematik; (4) koneksi matematik; (5) komunikasi matematik. Pemahaman matematika berkaitan dengan kemampuan siswa dalam menjawab suatu pertanyaan matematis yang disertai dengan alasan atas jawaban tersebut (mengapa siswa yang bersangkutan berasumsi bahwa jawabannya benar dengan dasar logisnya). Alasan-alasan tersebut bisa berupa definisi suatu konsep, penggunaan model dan simbol untuk mempresentasikan konsep, penerapan suatu perhitungan sederhana, penyelesaian suatu soal secara algoritmik yang dilakukan dengan benar dan menyadari proses demi proses yang dilakukan (step by step). Menurut Adjie dan Maulana (2006), pemecahan atau penyelesaian masalah merupakan proses penerimaan tantangan dan kerja keras untuk menyelesaikan masalah.Hal senada diungkapkan Wahyudin (2012), yang menyatakan bahwa pemecahan masalah merupakan bagian integral dalam proses pembelajaran matematika. Dengan demikian,pemecahan masalahtidak dapat dijadikan sebagai bagian yang terpisah dariproses pembelajaran yang dilaksanakan. Pada pembelajaran 
matematika khususnya, pemecahan masalahtidak hanya menjadi sasaran belajar, tetapi sekaligus sebagai cara untuk melakukan proses belajar itu sendiri.

Konekni matematis berasal dari Bahasa Inggris yaitu mathematical connection yang selanjutnya dipopulerkan oleh NCTM pada tahun 1989. NCTM (2000) menyatakan bahwa matematika bukan merupakan kumpulan topik dan kemampuan yang terpisah secara parsial, walaupun pada kenyataannya matematika sering dipartisi dan dipelajari dalam beberapa cabang. Matematika merupakan ilmu yang terintegrasi. Dengan asumsi tersebut, matematika perlu dipandang sebagai suatu keseluruhan yang bersifat holistik. Dengan demikian, memandang matematika secara keseluruhan sangat penting dalam belajar dan berpikir terkait koneksi antar topik dalam matematika itu sendiri. Struktur koneksi antarcabang matematika memungkinkan siswa melakukan penalaran matematik secara analitik dan sintesik.

Gilarso (dalam Setyono, http://setyono.blogspot.co.id/2008/07/) menyatakan bahwa penalaran merupakan suatu penjelasan yang menunjukkan kaitan atau hubungan antara dua hal atau lebih yang atas dasar alasan tertentu dan dengan langkah tertentu sampai pada satu kesimpulan. Hal senada dikatakan Nico (http://nicokani.blogspot.co.id/2012/03/) yang menyatakan bahwa penalaran merupakan sebuah pemikiran untuk dapat menghasilkan suatu kesimpulan. Komunikasi matematika merupakan salah satu kemampuan matematis yang diharapkan dapat dikuasai oleh siswa. Komunikasi matematika melibatkan 3 aspek (Vermont Department of Education, 2004), antara lain: (1) menggunakan bahasa matematika secara akurat dan menggunakannya untuk mengkomunikasikan aspek penyelesaian masalah; (2) menggunakan representasi matematika secara akurat untuk mengkomunikasikan penyelesaian masalah; (2) mempresentasikan penyelesaian masalah yang terorganisasi dan terstruktur dengan baik.

Dalam proses pembelajaran yang dilaksanakan, proses berpikir matematis senantiasa dikembangkan secara optimal dan signifikan. Implikasi dari asumsi tersebut bahwa proses pembelajaran yang dilaksanakan tidak hanya berlangsung dalam konteks one way communication tetapi harus melalui proses interaksi yang bersifat two way communication yaitu antara sesama siswa, siswa dengan guru, siswa dengan lingkungan dan sumber belajar. Dalam prosesnya, pembelajaran yang dilaksanakan harus dapat memberikan tantangan bagi siswa untuk berpikir secara kompleks terkait konsep materi 
yang sedang dipelajarinya. Di samping itu, siswa harus dapat menunjukkan kemampuan berpikirnya secara optimal dalam proses pembelajaran.

Pengembangan kemampuan berpikir matematis pada proses pembelajaran di SD perlu mendapat porsi yang lebih dalam kesehariannya. Kemampuan berpikir matematis pada dasarnya tidak hanya dikembangkan dalam proses pembelajaran matematika saja. Hal tersebut memberikan satu asumsi yang meyakinkan bahwa proses pembelajaran di luar mata pelajaran matematika (yang saat ini berdiri sendiri sebagai mata pelajaran di luar materi tematik terpadu) masih dapat diiringi dengan kemampuan berpikir matematis jika dilihat dari masing-masing dimensi berpikir matematis secara parsial. Namun demikian, proses yang holistik yang membentuk satu konsep terpadu dari kemampuan berpikir matematis dapat dikembangkan dalam proses pembelajaran di kelas. Dalam prosesnya, siswa dapat mengembangkan dan mengoptimalkan kemampuan berpikir matematisnya secara perlahan dalam sajian konsep pembelajaran yang menantang rasa inquiry siswa. Melalui stimulus-stimulus yang menantang kemampuan berpikir siswa, konsep pembelajaran yang mengindikasikan adanya dimensi berpikir matematis disajikan dalam konteks pembelajaran yang menantang siswa untuk berpikir lebih luas dan mendalam.

Bloom menyatakan bahwa dimensi kognitif sebagaimana pengembangan dari proses berpikir tingkat tinggi dibedakan menjadi 3 dimensi, antara lain: (1) faktual; (2) konseptual; (3) prosedural; (4) metakognisi. Adapun bila dilihat dari tingkatan kognitifnya, Bloom (sebagaimana revisi yang dilakukan Anderson dan Krathwohl: 2001) membagi level berpikir (kognisi) dalam 6 tingkatan, antara lain: (1) ingatan; (2) pemahaman; (3) penerapan; (4) analisis; (5) evaluasi; (6) kreasi. Dari keenam level tersebut, diidentifikasikan ke dalam 2 jenis level berpikir yaitu berpikir tingkat rendah (low order thinking skill) dan berpikir tingkat tinggi (high order thinking skill). Secara singkat dapat diidentifikasikan bahwa dari level 1 sampai dengan 3 merupakan golongan berpikir tingkat rendah sedangkan level 4 sampai dengan 6 merupakan aspek berpikir tingkat tinggi. Kaitannya dengan kemampuan berpikir matematis di sini bahwa, proses berpikir tingkat tinggi ini dapat dikembangkan seiring sejalan dengan kemampuan berpikir matematis yang memiliki 5 dimensi tersebut. Dengan demikian, konsekuensi proses pembelajaran yang dilakukan adalah perlunya pengembangan materi pembelajaran yang benar-benar menumbuhkembangkan high order thinking 
skilldari siswa itu sendiri. Di samping itu, dimensi kognitif yang berkaitan dengan konsep materi dapat dikembangkan secara teoretis dalam konteks praksis pembelajaran di kelas secara hierarkis kronologis. Sehingga kemampuan yang dikembangkan dan dikuasai siswa tidak hanya sebatas mengetahui dan menguasai konsep matematis secara teoretis, tetapi lebih kepada bagaimana siswa mampu menerapkan dan mengimplementasikan konsep teoretis dari materi matematika yang dipelajarinya dalam konteks praksis di lapangan sebagaimana proses kehidupan yang mereka alami seharihari. Dengan demikian, proses pembelajaran yang meaningfull learning benar-benar dapat diimplementasikan secara nyata di dalam kelas secara optimal.

Secara hierarkis dapat dilihat pada bagan berikut ini terkait konsep keterampilan berpikir tingkat tinggi (HOTS) dan berpikir tingkat rendah (LOTS) berdasarkan taksonomi bloom yang telah direvisi Anderson dan Krathwohl (2001)

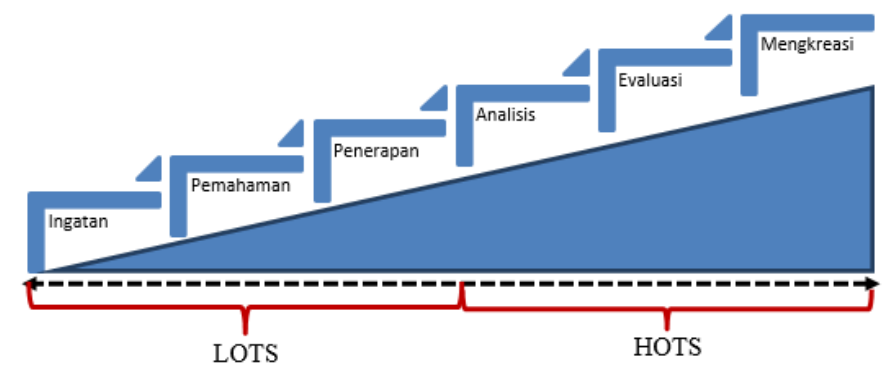

Gambar 2. Level kognitif berdasarkan taksonomi bloom (Revisi Anderson, 2001)

Bila dikorelasikan antara kemampuan berpikir tingkat tinggi, konsep pembelajaran abad 21, dan kemampuan berpikir matematis maka ketiganya merupakan bentuk-bentuk partisi yang masing-masing memiliki karakteristik yang berbeda. Akan tetapi, dalam proses pengembangannya khususnya dalam proses pembelajaran yang dilaksanakan, ketiganya akan bertemu pada satu bangunan konsep pembelajaran abad 21 yang sama-sama berangkat dari bagaimana siswa seharusnya belajar dan mempelajari sesuatu hal yang bermakna dalam kehidupannya. Secara praksis, ketiganya dapat dikembangkan dan dioptimalkan dalam proses pembelajaran karena sama-sama mengembangkan bagaimana siswa dapat dengan cakap dan terampil menguasai suatu kompetensi yang diharapkan sebagai bentuk pengalaman belajar dalam proses pembelajaran yang meaningfull learning. Dimensi pembelajaran abad 21 yang diharapkan beririsan dengan dimensi berpikir matematis, dalam proses praksisnya maka keduanya dapat dijadikan satu implementasi pembelajaran yang saling mengisi dan 
melengkapi satu dengan lainnya. Dengan demikian, kecakapan siswa dapat lebih optimal dalam melaksanakan proses pembelajaran di kelas.

\section{KESIMPULAN}

Proses berpikir matematis memberikan banyak kontribusi terhadap perkembangan berpikir siswa secara holistik dalam mengoptimalkan kapasitas dan kapabilitasnya sebagai peserta belajar. Kaitannya dengan hal tersebut, siswa ditempa dengan berbagai hal yang mendukung kemampuan berpikir tingkat tinggi.Dalam konteks perkembangan kehidupan selanjutnya, siswa akan dihadapkan pada kenyataan hidup yang menuntut mereka untuk berpikir secara realistis diiringi berbagai kapabilitasnya yang diperoleh sebagai pengalaman belajar di sekolah. Dengan demikian, kemampuan berpikir matematis memberikan andil besar terhadap perkembangan kapabilitas siswa dalam menghadapi kenyataan hidup pada masanya yang akan datang. Di samping itu, konteks pembelajaran abad 21 memberikan satu tantangan tersendiri bahwa siswa yang saat ini belajar di level sekolah dasar, nantinya akan menghadapi kenyataan hidup yang penuh tantangan dan menuntut pola pikir yang tinggi. Dalam waktunya nanti, diharapkan dapat dilahirkan generasi emas yang benarbenar siap menghadapi tantangan global yang serba unpredictable tetapi siswa-siswa nantinya akan dengan mudah menghadapi dan menyikapinya dengan tepat dan bijaksana.

\section{DAFTAR PUSTAKA}

Adjie, Nahrowi dan Maulana. (2006). Pemecahan Masalah Matematika. Bandung: UPI Press

Alismail, Halah Ahmed dan Patrick McGuire. 21st Century Standards and Curriculum: Current Research and Practice: Journal of Education and Practice, Vol 6, No. 6, 2015

Anderson, L. W. dan D. R. Krathwohl. (2001). A Taxonomy for Learning, Teaching, and Assesing: A Revision of Bloom's Taxonomy of Educational Objectives. Boston: Allyn \& Bacon

Darminto, B.P. (2008). Studi Perbandingan Model-model Pembelajaran Berbasis Komputer dalam Peningkatan Kemampuan Berpikir Matematis Tingkat Tinggi Calon Guru di Perguruan Tinggi Muhammadiyah. Disertasi PPS UPI Bandung (tidak diterbitkan)

Kusumaningrum, Maya dan Abdul Aziz Saefudin. Mengoptimalkan Kemampuan Berpikir Matematika Melalui Pemecahan Masalah Matematika:Prosiding pada 
Seminar Nasional Matematika dan Pendidikan Matematika FMIPA UNY 2012: P.60

NCTM. (2000). Principles and Standards for School Mathematics. The National Council of Teacher of Mathematics. Reston: Association Drive

Nichols, Jennifer Rita. "4 Essential Rules for 21st Century Learning” dalam http://www.teachthought.com/learning/4-essential-rules-of-21st-centurylearning/ (7 April 2017)

Nico. "Definisi Penalaran" dalam http://nicokani.blogspot.co.id/2012/03/definisipenalaran.html (7 April 2017)

Schoenfeld, A.H. (1992). Learning to Think Mathematically: Problem Solving, Metacognition, and Sense-making in Mathematics. In D. Grouws (Ed.), Handbook Research on Mathematics Teaching and Learning (hh. 334 - 370). New York: MacMillan

Setyono. "Peningkatan Kemampuan Penalaran Siswa dalam Pembelajaran Matematika" dalam http://setyono.blogspot.co.id/2008/07/bab-i-pendahuluan_09.html (7 April 2017)

Sumarno. (2006). Pembelajaran untuk Mengembangkan Kemampuan Berpikir Matematik, Makalah pada Seminar Nasional Pendidikan Matematika dan Ilmu Pengetahuan Alam, FPMIPA UPI

Vermont Department of Education. "Mathematics Problem Solving Criteria" dalam http://www.acsu.k12.vt.us/sclrpt97/MATHPRO.html (7 April 2017)

Wahyudin. (2012). Filsafat dan Model-model Pembelajaran Matematika. Bandung: Mandiri 